\title{
Genetic determinants of the humoral immune response in MS
}

Christiane Gasperi, MD, Till F.M. Andlauer, PhD, Ana Keating, MSc, Benjamin Knier, MD, Ana Klein, MD, Verena Pernpeintner, MD, Peter Lichtner, PhD, Ralf Gold, MD, Frauke Zipp, MD, Florian Then Bergh, MD, Martin Stangel, MD, Hayrettin Tumani, MD, Brigitte Wildemann, MD, Heinz Wiendl, MD, Antonios Bayas, MD, Tania Kümpfel, MD, Uwe K. Zettl, MD, Ralf A. Linker, MD, Ulf Ziemann, MD, Matthias Knop, MD, Clemens Warnke, MD, Manuel A. Friese, MD, Friedemann Paul, MD, Björn Tackenberg, MD, Achim Berthele, MD, and Bernhard Hemmer, MD

Neurol Neuroimmunol Neuroinflamm 2020;7:e827. doi:10.1212/NXI.0000000000000827

\section{Abstract}

\section{Objective}

In this observational study, we investigated the impact of genetic factors at the immunoglobulin heavy chain constant locus on chromosome 14 and the major histocompatibility complex region on intrathecal immunoglobulin G, A, and M levels as well as on B cells and plasmablasts in the CSF and blood of patients with multiple sclerosis (MS).

\section{Methods}

Using regression analyses, we tested genetic variants on chromosome 14 and imputed human leukocyte antigen (HLA) alleles for associations with intrathecal immunoglobulins in 1,279 patients with MS or clinically isolated syndrome and with blood and CSF B cells and plasmablasts in 301 and 348 patients, respectively.

\section{Results}

The minor alleles of variants on chromosome 14 were associated with higher intrathecal immunoglobulin $G$ levels $\left(\beta=0.58[0.47\right.$ to 0.68$]$, lowest adjusted $\left.p=2.32 \times 10^{-23}\right)$, and lower intrathecal immunoglobulin $\mathrm{M}\left(\beta=-0.56[-0.67\right.$ to -0.46$\left.], p=2.06 \times 10^{-24}\right)$ and $\mathrm{A}(\beta=-0.42$ $[-0.54$ to -0.31$\left.], p=7.48 \times 10^{-11}\right)$ levels. Alleles from the HLA-B ${ }^{*} 07: 02-D R B 1^{*} 15: 01-D Q A 1 * 01$ : 02-DQB1 ${ }^{*} 06: 02$ haplotype were associated with higher (lowest $p=2.14 \times 10^{-7}$ ) and HLA-B*44: 02 with lower $\left(\beta=-0.35[-0.54\right.$ to -0.17$\left.], p=1.38 \times 10^{-2}\right)$ immunoglobulin $\mathrm{G}$ levels. Of interest, different HLA alleles were associated with lower intrathecal immunoglobulin M (HLA-C*02:02, $\beta=-0.45[-0.61$ to -0.28$], p=1.01 \times 10^{-5}$ ) and higher immunoglobulin $\mathrm{A}$ levels (HLA-DQA1 ${ }^{*} 01: 03-D Q B 1{ }^{*} 06: 03-D R B 11^{*} 13: 01$ haplotype, $\beta=0.40[0.21$ to 0.60$], p=4.46 \times$ $\left.10^{-3}\right)$. The impact of HLA alleles on intrathecal immunoglobulin $\mathrm{G}$ and $\mathrm{M}$ levels could mostly be explained by associations with CSF B cells and plasmablasts.

\section{Conclusion}

Although some HLA alleles seem to primarily drive the extent of humoral immune responses in the CNS by increasing CSF B cells and plasmablasts, genetic variants at the immunoglobulin heavy chain constant locus might regulate intrathecal immunoglobulins levels via different mechanisms.

\author{
Correspondence \\ Dr. Hemmer \\ hemmer@tum.de
}




\section{Glossary}

CIS = clinically isolated syndrome; GWAS = genome-wide association study; HLA = human leukocyte antigen; IgA = immunoglobulin A; IgG = immunoglobulin G; IGHC = immunoglobulin heavy chain constant; IGHG = immunoglobulin heavy constant gamma; IgM = immunoglobulin M; LD = linkage disequilibrium; $\mathbf{M H C}=$ major histocompatibility complex; SNP = single nucleotide polymorphism .

An elevated immunoglobulin $\mathrm{G}(\mathrm{IgG})$ index is seen in $70 \%$ of patients with multiple sclerosis (MS), whereas intrathecal synthesis of immunoglobulin $\mathrm{M}$ (IgM) and immunoglobulin A (IgA) occurs less frequently ( $20 \%$ and $9 \%$, respectively). ${ }^{1} \mathrm{Al}-$ though the amount of intrathecal production of Igs varies strongly between patients, it remains relatively stable over the disease course-even under disease-modifying treatment. ${ }^{2-4}$ A genetic contribution to intrathecal Ig synthesis, therefore, likely exists.

We could previously demonstrate in a genome-wide association study (GWAS) that genetic variants located at the immunoglobulin heavy chain constant (IGHC) locus on chromosome 14 are associated with the IgG index in patients with MS or clinically isolated syndrome (CIS). ${ }^{5}$ This finding was replicated in a large multicenter GWAS. ${ }^{6}$

In addition, the GWAS by Goris et al. ${ }^{6}$ showed that the haplotype rs $9271640^{*} \mathrm{~A}-\mathrm{rs} 6457617^{*} \mathrm{G}$ that correlates with the human leukocyte antigen (HLA) allele HLA-DRB1*15: 01 - the strongest known MS risk allele ${ }^{7,8}$ — was also associated with higher IgG indices.

The aim of the present study was to further investigate the influence of genetic variants and HLA alleles on intrathecal immunoglobulin synthesis in a large cohort of patients with MS or CIS. Based on our previous findings, we aimed at a more detailed characterization of the association of the IGHC locus and not only intrathecal IgG but also IgM and IgA levels. To further elucidate the mechanisms by which the genetic variants alter the intrathecal immune response, we analyzed possible associations with serum concentrations of $\operatorname{IgG}, \operatorname{IgA}$, and $\operatorname{IgM}$, as well as with the proportion of B cells and plasmablasts in CSF and blood.

\section{Methods}

\section{Cohorts}

We analyzed DNA samples of 1,279 patients with MS or CIS including all patients with available DNA samples and CSF data at the Klinikum rechts der Isar of the Technical University of Munich as well as patients recruited by the German MS competence network. ${ }^{9}$ Diagnosis was based on standard diagnostic criteria. ${ }^{10-13}$ Of 2,559 patients with available DNA, we excluded all patients with missing data on sex, age, or date of lumbar puncture. In all patients, lumbar puncture had been performed as part of the diagnostic workup. We performed quality control on available genetic data as described below and excluded patients without available genome-wide chip data.

\section{Standard protocol approvals, registrations, and patient consents}

We obtained written informed consent from all patients according to the Declaration of Helsinki and collected samples with ethical approval at the recruitment sites. The ethic committee at the Technical University of Munich approved the study.

\section{CSF protein analysis}

CSF analysis was performed at each center independently. If CSF data from more than 1 time point were available, we only considered the first CSF sampling data. CSF and serum concentrations for albumin and the 3 Ig classes IgG, IgM, and IgA were measured in parallel by standard turbidimetric or nephelometric assays, depending on the center. We calculated $\mathrm{CSF}$ /serum quotients (QIgG, QIgM, QIgA, and Qalb) as well as IgG, IgM, and IgA indices as QIgG/Qalb, QIgM/Qalb, and QIgA/Qalb, respectively.

\section{Flow cytometric analysis}

We performed flow cytometric analysis of CSF and blood immune cells for 348 and 301 treatment-naive patients, respectively, as described previously. ${ }^{14}$ Flow cytometry data were available only for patients treated at the Klinikum rechts der Isar. We used the following antibodies for staining of $B$ cells and plasmablasts: CD45 (clone HI30, BD Biosciences), CD19 (clone J3.119, Beckman Coulter), and CD138 (clone B-A38, Beckman Coulter) and analyzed the stained cells using a flow cytometer (CyAn ADP, Beckman Coulter). We then gated the cells on CD45 to select all leukocytes and subsequently on $\mathrm{CD} 19\left(\mathrm{CD}_{4} 5^{+} \mathrm{CD} 19^{+} \mathrm{B}\right.$ cells) and $\mathrm{CD} 138\left(\mathrm{CD} 45^{+} \mathrm{CD} 19^{+}\right.$ $\mathrm{CD} 138^{+}$plasmablasts). We determined cell numbers using FlowJo v10 (FlowJo LLC) and calculated percentages of B cells and plasmablasts of all CD $45^{+}$cells.

\section{Genotyping and quality control}

The previously described variants at the IGHC locus associated with the IgG index are not well represented on most of the available whole-genome genotyping microarrays. We therefore genotyped 16 single nucleotide polymorphisms (SNPs) at the IGHC locus on a MassARRAY system using MALDI-TOF mass spectrometry with iPLEX Gold chemistry (Agena) and called genotypes with Typer Analyzer 4.0.22.67. For genotyping, we collected DNA samples from venous blood and stored the samples at $-80^{\circ} \mathrm{C}$. During quality control, we excluded variants with a minor allele frequency $<1 \%$, a Hardy-Weinberg equilibrium test $p$ value $<0.0001$, or a call rate $<98 \%$, leaving 13 variants for further analysis. Genome-wide genotyping SNP data had been acquired using 2 different microarrays (Illumina 
OmniExpress v1.0, v1.1, and v1.2 and Illumina 660-Quad) in different batches at the Max Planck Institute of Psychiatry in Munich, Germany, the Helmholtz Zentrum Munich in Neuherberg, Germany, and the Wellcome Trust Sanger Institute in Cambridge, United Kingdom. Genotype calling had been performed with GenomeStudio Genotyping Module v2.0 or with Illuminus. ${ }^{15}$ We conducted quality control of the genotype data using PLINK v1.90b6.9 $9^{16,17}$ as described previously. ${ }^{8} \mathrm{We}$ excluded individuals with a genotyping rate $<98 \%$, cryptic relatedness $>1 / 8$, and any genetic outliers with a distance in the first 2 multidimensional scaling ancestry components of the identity-by-state matrix of $>5$ SDs. We further excluded individuals with deviation of autosomal heterozygosity $>4$ SDs from the mean and individuals with heterozygosity on the $\mathrm{X}$ chromosome of $<-0.2$.

\section{HLA imputation}

We performed HLA allele imputation using SNP2HLA v1.0.3 (Beagle v3.04) and the Type 1 Diabetes Genetics Consortium imputation panel, as previously described. ${ }^{18-20}$ After quality control, we selected 98 HLA alleles with 4-digit resolution, an allele frequency of $\geq 1 \%$, and a Beagle imputation $r^{2} \geq 0.3$ for further analysis. We also analyzed the following haplotypes determined using Beagle phasing results: HLA-A*03:01$\mathrm{C}^{*}$ 07:02-B*07:02-DRB1*15:01-DQA1 ${ }^{*} 01: 02-\mathrm{DQB1}{ }^{*} 06: 02$, HLA-DQA1 ${ }^{*} 01: 03-D Q B 11^{*} 06: 03-D R B 11^{*} 13: 01, \quad$ HLA-A ${ }^{*} 02$ : 01-B*4:02-C*05:01-DRB1*04:01, and HLA-A*02:01-B ${ }^{*} 27$ : 02-C ${ }^{*} 02: 02-\mathrm{DRB1}{ }^{*} 16: 01$.

\section{Linkage disequilibrium of the variants on chromosome 14 and HLA alleles}

Of 16 genotyped variants, 13 variants at the IGHC locus passed quality control. Using a linkage disequilibrium (LD) threshold of $r^{2}>0.7$, we defined 4 LD groups: A: rs10136766, rs1071803, rs111608686, rs1134590, rs11621145, rs12884389, rs12897751, rs2725142, rs2753571, and rs34398108; B: rs1059216; C: rs61984162; and D: rs8009156. For the 4-digit HLA alleles, 7 LD groups with 2 members each and 5 LD groups with 3 alleles could be identified. We calculated LD using PLINK v1.90b6.9. ${ }^{16,17}$

\section{Statistical analyses}

As the primary analysis, we investigated associations of the genotyped variants on chromosome 14 and the imputed HLA alleles with Ig indices (transformed by inverse rank normalization) by linear regression. For the IGHC variants, we either chose a dominant or an additive allelic model for the regression analyses, following visual inspection of the data, and included sex, age at lumbar puncture, and the sequencing plate as covariates. For the imputed HLA alleles, we analyzed dosage data $(2 \times$ the probability for being homozygous for the allele $+1 \times$ the probability for being heterozygous) using the same covariates except the sequencing plate. To correct for population stratification, we added up to 5 first multidimensional scaling components as covariates if they were associated either with the dependent variable or the investigated variant or HLA allele. The DNA samples had been genotyped using 2 different microarray types. As visual inspection of the multidimensional scaling components showed no distinction between these data sets, we did not include the genotyping chip as a covariate. We determined homoscedasticity of regression residuals using the Breusch-Pagan test; for models showing evidence for heteroscedasticity, we used robust sandwich error estimators ( $\mathrm{R}$ package sandwich). We tested the normality of residuals by a Shapiro-Wilk test and corrected $p$ values for multiple testing using the Bonferroni procedure for the number of LD groups with $r^{2}>0.7(n=85$ independent tests, $4 \mathrm{LD}$ groups of the chromosome 14 variants, and 81 HLA allele LD groups). To determine the phenotypic variance explained by the analyzed genetic variants $\left(R^{2}\right)$, we conducted linear regression analyses using the residuals from a null model including all covariates as the dependent variable and the respective genetic variant as the independent variable.

We carried all variants and HLA alleles significantly associated with any of the Ig indices forward to secondary exploratory analyses on their associations with rank-transformed Ig serum concentrations and proportions of CSF and blood B cells $\left(\mathrm{CD}_{4}{ }^{+} \mathrm{CD} 19^{+}\right.$cells) and plasmablasts $\left(\mathrm{CD} 45^{+} \mathrm{CD} 19^{+}\right.$ $\mathrm{CD} 138^{+}$cells). IgM indices and serum IgM concentrations did not follow a normal distribution after inverse rank transformation. We therefore validated associations with these traits using permutation analyses (100,000 permutations). We performed causal mediation analyses including nonparametric bootstrap for estimation of CIs and $p$ values using the $\mathrm{R}$ package mediation ${ }^{21}$ with the same covariates as described above with 10,000 simulations. We performed all statistical analyses using $\mathrm{R}$ v3.5.1. ${ }^{22}$

\section{Data availability}

The data that support the findings of this study are available from the corresponding author on reasonable request.

\section{Results}

\section{Study cohort, CSF, and flow cytometry data}

Table e-1, links.lww.com/NXI/A277, shows the demographic data and aggregated CSF and flow cytometry parameters for all 1,279 patients. Four hundred twenty of these samples were included in one or both of the mentioned previous genetic studies on IgG indices. ${ }^{5,6}$ We observed significant correlations between all $3 \mathrm{Ig}$ indices (Spearman $\rho=0.26$, 95\% CI $[0.20-0.31]$ for IgG and IgM indices; $\rho=0.18[0.12-0.24]$ for IgG and IgA indices; and $\rho=0.47[0.42-0.52]$ for IgM and IgA indices).

\section{Genetic factors at the IGHC locus associated with Ig indices}

The minor alleles of all 10 variants from LD group $A$ on chromosome 14 were associated with higher IgG indices (table 1 and figure 1A). All 10 variants were also significantly associated with IgA and IgM indices. However, these associations had a reversed sign, i.e., the minor alleles were 
Table 1 Association of variants on chromosome 14 with the Ig indices

\begin{tabular}{|c|c|c|c|c|c|c|c|c|c|c|c|}
\hline \multirow[b]{2}{*}{ Variant (LD group) } & \multirow[b]{2}{*}{ EA } & \multirow[b]{2}{*}{ AF } & \multicolumn{3}{|c|}{ Regression on IgG indices } & \multicolumn{3}{|c|}{ Regression on IgM indices } & \multicolumn{3}{|c|}{ Regression on IgA indices } \\
\hline & & & $\beta(95 \% \mathrm{Cl})$ & Adjusted $p$ & $\mathbf{N}$ & $\beta(95 \% \mathrm{Cl})$ & Adjusted $p$ & $\mathbf{N}$ & $\beta(95 \% \mathrm{Cl})$ & Adjusted $p$ & $\mathbf{N}$ \\
\hline s10136766 (A) & A & 25.5 & 0.57 (0.46 to 0.68$)$ & $1.02 \times 10^{-21}$ & 1,229 & $-0.55(-0.65$ to -0.44$)$ & $6.35 \times 10^{-22}$ & 1,151 & $-0.41(-0.53$ to -0.30$)$ & $3.57 \times 10^{-10}$ & 1,143 \\
\hline s1071803 (A) & $\mathrm{T}$ & 25.8 & 0.57 (0.46 to 0.68$)$ & $1.34 \times 10^{-21}$ & 1,227 & $-0.57(-0.67$ to -0.46$)$ & $1.51 \times 10^{-23}$ & 1,150 & $-0.41(-0.52$ to -0.29$)$ & $7.79 \times 10^{-10}$ & 1,142 \\
\hline s11160868 (A) & $\mathrm{T}$ & 25.7 & 0.58 (0.47 to 0.68 ) & $2.32 \times 10^{-23}$ & 1,262 & $-0.56(-0.66$ to -0.45$)$ & $2.61 \times 10^{-23}$ & 1,189 & $-0.39(-0.50$ to -0.27$)$ & $2.69 \times 10^{-09}$ & 1,181 \\
\hline s1134590 (A) & c & 21.8 & 0.55 (0.43 to 0.66$)$ & $2.89 \times 10^{-19}$ & 1,262 & $-0.47(-0.58$ to -0.36$)$ & $1.37 \times 10^{-15}$ & 1,185 & $-0.37(-0.49$ to -0.26$)$ & $3.34 \times 10^{-08}$ & 1,177 \\
\hline s11621145 (A) & G & 27.1 & 0.53 (0.42 to 0.64 ) & $8.39 \times 10^{-19}$ & 1,227 & $-0.53(-0.64$ to -0.42$)$ & $2.22 \times 10^{-20}$ & 1,149 & $-0.40(-0.52$ to -0.29$)$ & $1.05 \times 10^{-09}$ & 1,141 \\
\hline$s 12884389$ (A) & C & 28.7 & 0.51 (0.40 to 0.62 ) & $1.72 \times 10^{-17}$ & 1,229 & $-0.48(-0.59$ to -0.37$)$ & $2.51 \times 10^{-16}$ & 1,152 & $-0.42(-0.54$ to -0.31$)$ & $7.48 \times 10^{-11}$ & 1,144 \\
\hline s12897751 (A) & G & 25.6 & 0.57 (0.46 to 0.68 ) & $4.92 \times 10^{-23}$ & 1,278 & $-0.56(-0.67$ to -0.46$)$ & $2.06 \times 10^{-24}$ & 1,200 & $-0.40(-0.51$ to -0.29$)$ & $4.05 \times 10^{-10}$ & 1,192 \\
\hline$s 2725142(A)$ & G & 29.0 & 0.51 (0.40 to 0.62 ) & $1.13 \times 10^{-17}$ & 1,233 & $-0.48(-0.59$ to -0.37$)$ & $1.46 \times 10^{-16}$ & 1,156 & $-0.40(-0.51$ to -0.28$)$ & $1.07 \times 10^{-09}$ & 1,148 \\
\hline$s 2753571$ (A) & A & 29.1 & 0.51 (0.40 to 0.62 ) & $3.65 \times 10^{-18}$ & 1,231 & $-0.46(-0.57$ to -0.36$)$ & $3.11 \times 10^{-15}$ & 1,154 & $-0.39(-0.50$ to -0.27$)$ & $4.50 \times 10^{-09}$ & 1,146 \\
\hline s34398108 (A) & A & 27.9 & 0.52 (0.42 to 0.63 ) & $2.40 \times 10^{-19}$ & 1,229 & $-0.54(-0.64$ to -0.43$)$ & $2.71 \times 10^{-21}$ & 1,153 & $-0.40(-0.51$ to -0.28$)$ & $1.19 \times 10^{-09}$ & 1,145 \\
\hline s1059216 (B) & c & 6.2 & $-0.10(-0.27$ to 0.07$)$ & $1.00 \times 10^{-00}$ & 1,270 & $-0.17(-0.33$ to 0.00$)$ & $1.00 \times 10^{-00}$ & 1,193 & $-0.12(-0.30$ to 0.05$)$ & $1.00 \times 10^{-00}$ & 1,185 \\
\hline$s 61984162$ (C) & A & 2.8 & $0.20(-0.04$ to 0.45$)$ & $1.00 \times 10^{-00}$ & 1,276 & $-0.20(-0.44$ to 0.04$)$ & $1.00 \times 10^{-00}$ & 1,198 & -0.15 ( -0.40 to 0.11$)$ & $1.00 \times 10^{-00}$ & 1,190 \\
\hline$s 8009156$ (D) & $\mathrm{T}$ & 44.8 & $-0.21(-0.29$ to -0.13$)$ & $5.80 \times 10^{-06}$ & 1,256 & 0.19 (0.11 to 0.26$)$ & $1.07 \times 10^{-04}$ & 1,178 & 0.14 (0.06 to 0.22 ) & $5.18 \times 10^{-02}$ & 1,170 \\
\hline
\end{tabular}

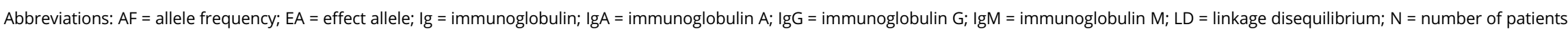

Linear regression on Ig indices transformed by inverse rank normalization and variants on chromosome 14. $p$ Values were adjusted by Bonferroni correction for multiple testing for $\mathrm{n}=85$ tests. 
Figure $1 \mathrm{lg}$ indices in carriers and noncarriers of the effect alleles of variants on chromosome 14

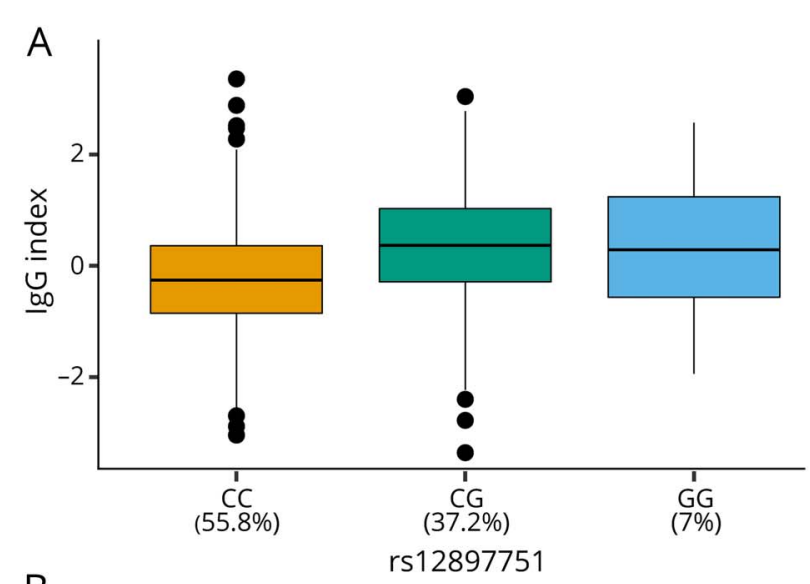

B

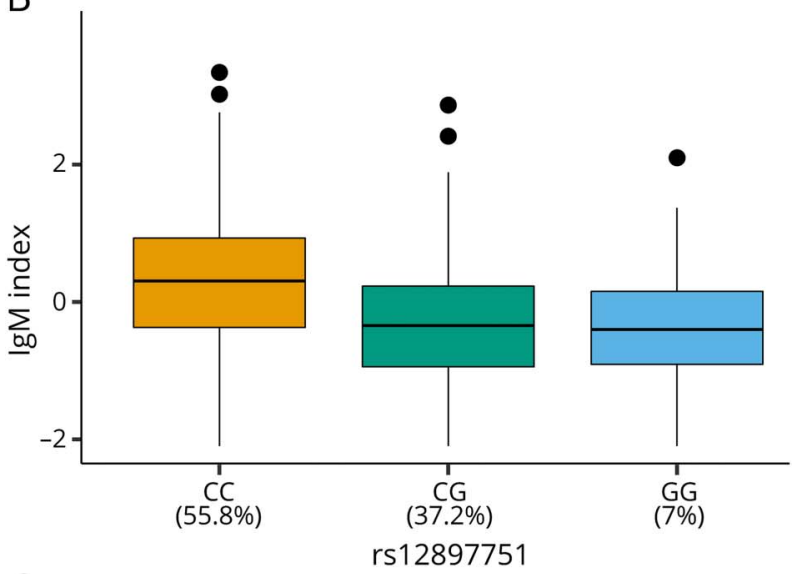

C

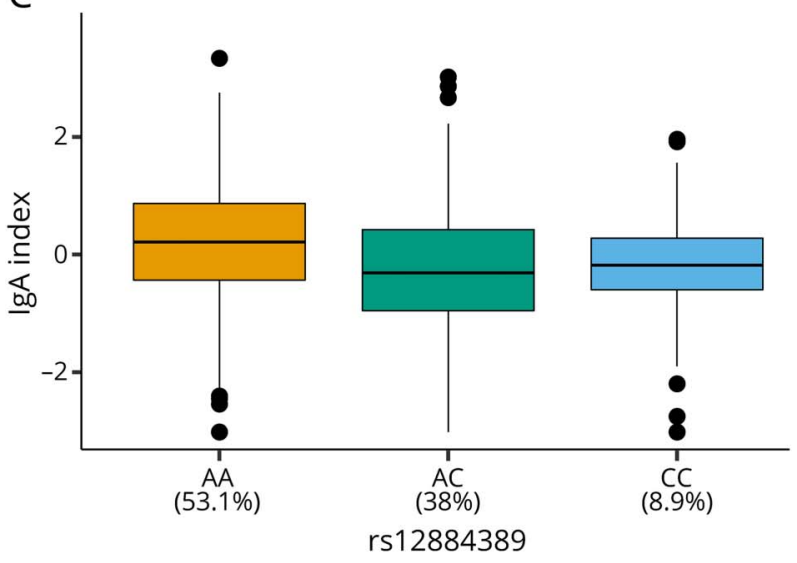

Box plots showing $\lg G(A), \lg M(B)$, and $\lg A(C)$ indices transformed by inverse rank normalization for noncarriers, heterozygotes, and homozygotes of the effect allele of the most significantly associated variants on chromosome 14. Bars represent the median, boxes the interquartile ranges, the vertical lines the data range without outliers, and dots the outliers.

associated with lower IgM (figure 1B) and IgA (figure 1C) indices (table 1). Visual evaluation of the rank-transformed $\mathrm{Ig}$ indices by genotype for these variants was consistent with a dominant model of inheritance. The minor allele rs $8009156^{*} \mathrm{~T}$ was associated with lower IgG indices and higher IgM and IgA indices, but the association with IgA indices was not significant after correction for multiple testing. Associations for the
IgM index were validated using permutation analyses (data not shown).

To fine map the association of variants at the IGHC locus with Ig indices, we performed stepwise conditional regression analyses, adjusting, in each step, for the variants with the most robust support for association. For IgG indices, we identified rs12897751 as the top-associated variant (explaining $7.6 \%$ of IgG index variance) and observed no evidence for a second causal effect at this locus. SNP rs12897751 also showed the most robust association with IgM indices (explaining $8.2 \%$ of the variance), and we observed weak evidence for a possible second causal effect: SNP rs34398109 was associated at nominal significance when conditioning for $\operatorname{rs} 12897751(\beta=-0.24[-0.47$ to -0.01 ], $p=0.037)$. For IgA indices, rs12884389 was the top-associated SNP, explaining $4.2 \%$ of the variance, and there was weak evidence for a second effect because rs11621145 was associated at nominal significance in the conditional analysis $(\beta=-0.19[-0.37$ to -0.01$]$, $p=0.035$ ).

\section{Association of HLA alleles with Ig indices}

Of 98 analyzed 4-digit HLA alleles, 9 showed an association with at least 1 of the $3 \mathrm{Ig}$ indices after correction for multiple testing (table 2). HLA-DRB1*15:01, HLA-DQB1*06:02, HLA-DQA ${ }^{*} 01: 02$, and HLA-B*07:02 were all significantly associated with higher IgG indices (figure $2 \mathrm{~A}$ for HLA$\mathrm{DQB1} 1^{*}$ 06:02). We performed haplotype level analyses on the extended HLA-A*03:01-C*07:02-B*07:02-DRB1*15:01$\mathrm{DQA1}^{*}$ 01:02-DQB1*06:02 haplotype with stepwise addition of the single HLA alleles of this haplotype. The most robust support for association could be observed for the HLA-DRB1*15:01-DQA1*01:02-DQB1*06:02 haplotype that explained $2.6 \%$ of the variance of $\operatorname{IgG}$ indices. When analyzed separately, HLA-DQB1*06:02 showed the most robust association. In addition, HLA-B*44:02 showed an association with lower IgG indices, explaining $1.0 \%$ of the IgG index variance. This association was independent of the HLA-DRB1*15:01-DQA1*01:02-DQB1*06:02 haplotype in a conditional analysis $(\beta=-0.34[-0.52$ to -0.16$]$, unadjusted $\left.p=2.64 \times 10^{-04}\right)$.

Only HLA-C*02:02 was associated with IgM indices after correction for multiple testing. This allele was associated with lower IgM indices, explaining $1.8 \%$ of the variance. All HLA alleles significantly associated with IgG indices were also associated with IgM indices at a nominal significance level (table 2 and figure 2B), but these associations were not significant after correction for multiple testing.

HLA-DRB1 ${ }^{*}$ 13:01, HLA-DQB1 ${ }^{*} 06: 03$, and HLA-DQA1 ${ }^{*} 01$ : 03 were associated with higher IgA indices. All 3 HLA alleles are part of the HLA-DQA1*01:03-DQB1 ${ }^{*} 06: 03-D R B 1{ }^{*}$ 13:01 haplotype, and the association of the haplotype was stronger than the association of the single alleles, explaining $1.6 \%$ of the IgA index variance (table 2). 
Table 2 Associations of HLA alleles with the Ig indices

\begin{tabular}{|c|c|c|c|c|c|c|c|}
\hline \multirow[b]{2}{*}{ HLA allele } & \multirow[b]{2}{*}{ AF } & \multicolumn{2}{|c|}{$\begin{array}{l}\text { Regression on IgG indices } \\
\text { (no. of patients }=1,279)\end{array}$} & \multicolumn{2}{|c|}{$\begin{array}{l}\text { Regression on IgM indices } \\
\text { (no. of patients }=1,200)\end{array}$} & \multicolumn{2}{|c|}{$\begin{array}{l}\text { Regression on IgA indices } \\
\text { (no. of patients }=1,192 \text { ) }\end{array}$} \\
\hline & & $\beta(95 \% \mathrm{Cl})$ & Adjusted $p$ & $\beta(95 \% \mathrm{Cl})$ & Adjusted $p$ & $\beta(95 \% \mathrm{Cl})$ & Adjusted $p$ \\
\hline$B * 07: 02$ & 17.8 & 0.18 (0.08 to 0.28$)$ & $2.92 \times 10^{-02}$ & $0.12(0.02$ to 0.22$)$ & $1.00 \times 10^{-00}$ & $0.09(-0.02$ to 0.19$)$ & $1.00 \times 10^{-00}$ \\
\hline DQA1*01:02 & 33.0 & 0.17 (0.09 to 0.25$)$ & $7.61 \times 10^{-03}$ & 0.11 (0.02 to 0.19$)$ & $1.00 \times 10^{-00}$ & $0.05(-0.04$ to 0.13$)$ & $1.00 \times 10^{-00}$ \\
\hline DQB1*06:02 & 26.5 & 0.27 (0.18 to 0.36$)$ & $2.41 \times 10^{-07}$ & 0.15 (0.06 to 0.24$)$ & $1.05 \times 10^{-01}$ & 0.09 (0.00 to 0.19$)$ & $1.00 \times 10^{-00}$ \\
\hline DRB1*15:01 & 27.3 & 0.24 (0.16 to 0.33$)$ & $5.92 \times 10^{-06}$ & 0.13 (0.05 to 0.22$)$ & $2.57 \times 10^{-01}$ & 0.09 (0.00 to 0.18$)$ & $1.00 \times 10^{-00}$ \\
\hline DQA1*01:03 & 6.0 & $0.10(-0.07$ to 0.26$)$ & $1.00 \times 10^{-00}$ & $0.15(-0.02$ to 0.31$)$ & $1.00 \times 10^{-00}$ & 0.37 (0.19 to 0.56$)$ & $6.71 \times 10^{-03}$ \\
\hline DQB1*06:03 & 5.5 & $0.06(-0.10$ to 0.22$)$ & $1.00 \times 10^{-00}$ & 0.17 (0.00 to 0.33$)$ & $1.00 \times 10^{-00}$ & 0.34 (0.15 to 0.53$)$ & $3.40 \times 10^{-02}$ \\
\hline DRB1*13:01 & 5.4 & $0.10(-0.07$ to 0.27$)$ & $1.00 \times 10^{-00}$ & 0.18 (0.01 to 0.35$)$ & $1.00 \times 10^{-00}$ & 0.39 (0.19 to 0.59$)$ & $8.59 \times 10^{-03}$ \\
\hline$B * 44: 02$ & 4.5 & $-0.35(-0.54$ to -0.17$)$ & $1.38 \times 10^{-02}$ & $-0.25(-0.45$ to -0.05$)$ & $7.44 \times 10^{-01}$ & $-0.03(-0.25$ to 0.18$)$ & $1.00 \times 10^{-00}$ \\
\hline$C * 02: 02$ & 4.3 & $-0.19(-0.38$ to -0.01$)$ & $1.00 \times 10^{-00}$ & $-0.45(-0.61$ to -0.28$)$ & $1.01 \times 10^{-05}$ & $-0.22(-0.41$ to -0.03$)$ & $1.00 \times 10^{-00}$ \\
\hline Haplotype1 & 26.0 & 0.27 (0.18 to 0.36$)$ & $2.14 \times 10^{-07}$ & 0.15 (0.06 to 0.24$)$ & $9.07 \times 10^{-02}$ & 0.10 (0.01 to 0.19$)$ & $1.00 \times 10^{-00}$ \\
\hline Haplotype2 & 5.5 & $0.11(-0.06$ to 0.28$)$ & $1.00 \times 10^{-00}$ & 0.18 (0.01 to 0.35$)$ & $1.00 \times 10^{-00}$ & $0.40(0.21$ to 0.60$)$ & $4.46 \times 10^{-03}$ \\
\hline
\end{tabular}

Abbreviations: AF = allele frequency; Haplotype1 = HLA-DRB1*15:01-DQA1*01:02-DQB1*06:02; Haplotype2 = HLA-DQA1*01:03-DQB1*06:03-DRB1*13:01; HLA = human leukocyte antigen; Ig = immunoglobulin; IgA = immunoglobulin A; IgG = immunoglobulin G; IgM = immunoglobulin M; LD = linkage disequilibrium.

Linear regression on Ig indices transformed by inverse rank normalization and 4-digit imputed HLA alleles. $p$ Values were adjusted by Bonferroni correction for multiple testing for $\mathrm{n}=85$ tests.

\section{Association of genetic variants and HLA alleles with serum Ig concentrations}

To further investigate the mechanisms by which the genetic factors might have an effect on Ig indices, we performed secondary regression analyses on blood Ig concentrations for variants and HLA alleles associated with Ig indices. Except for rs8009156, the minor alleles of all other variants on chromosome 14 associated with IgG indices were also associated with higher IgG serum levels, but the effect sizes of these associations were smaller compared with the analyses on IgG indices $(\beta=0.15-0.28$, data not shown). There was no association of any of the analyzed variants at the IGHC locus with serum IgM concentrations, and only rs 12897751 was associated with lower serum IgA concentrations. There was no association of any HLA allele with serum Ig levels after correction for multiple testing (data not shown).

\section{Association of genetic variants and HLA alleles with blood and CSF B cells and plasmablasts}

Of the analyzed variants on chromosome 14, only rs 2725142 and rs2753571 showed an association with proportions of CSF $\mathrm{B}$ cells $(\beta=-0.29[-0.52$ to -0.07$]$, adjusted $p=0.022$ for both variants), but were associated with a lower proportion of CSF $\mathrm{B}$ cells. None of the other analyzed variants on chromosome 14 were significantly associated with the proportions of $\mathrm{B}$ cells and plasmablasts in the CSF or peripheral blood (data not shown). HLA-DRB1*15:01 was associated with higher CSF B cell and plasmablast proportions and HLA-DQB1*06:02 and HLA-DQA1*01:02 with higher CSF plasmablast proportions (table 3 and figure 2 shown for HLA-DQB* $06: 02$ as this was the HLA allele with the strongest association with the IgG indices). HLA-C ${ }^{*} 02: 02$ was associated with lower CSF $B$ cell and plasmablast proportions (table 3). HLA-DRB1*13: 01, HLA-DQA1*01:03, HLA-DQB1*06:03, and HLA-B*44:02 were not associated with CSF B cells or plasmablasts. There was no significant association of any HLA allele associated with the Ig indices with percentages of peripheral blood B cells or plasmablasts (data not shown).

To investigate whether the association of the HLA alleles from the HLA-DRB1 ${ }^{*} 15: 01-D Q A 1^{*} 01: 02-D Q B 1{ }^{*} 06: 02$ haplotype and HLA-C*02:02 with CSF B cell and plasmablast proportions fully explains the associations with the $\mathrm{Ig}$ indices, we performed causal mediation analyses. These analyses could only be performed in a smaller proportion of the patients with available flow cytometry data and showed nominally significant results. We observed full mediation of the effect of the HLA alleles from the HLA-DRB1*15:01DQA1 ${ }^{*} 01: 02-D Q B 11^{*} 06: 02$ haplotype on IgG indices by increased CSF B cell or plasmablast proportions (shown for HLA-DQB1*06:02 in figure e-1, links.lww.com/NXI/ A277) and full mediation of the effect of HLA-C*02:02 on IgM indices by decreased CSF plasmablast proportions (figure e-1, links.lww.com/NXI/A277).

\section{Epistasis between genetic factors at the IGHC locus and HLA alleles on Ig indices}

We tested for epistatic interactions between the variants at the IGHC locus and HLA alleles. No significant interactions were found between the top-associated IGHC variant, rs12897751, 


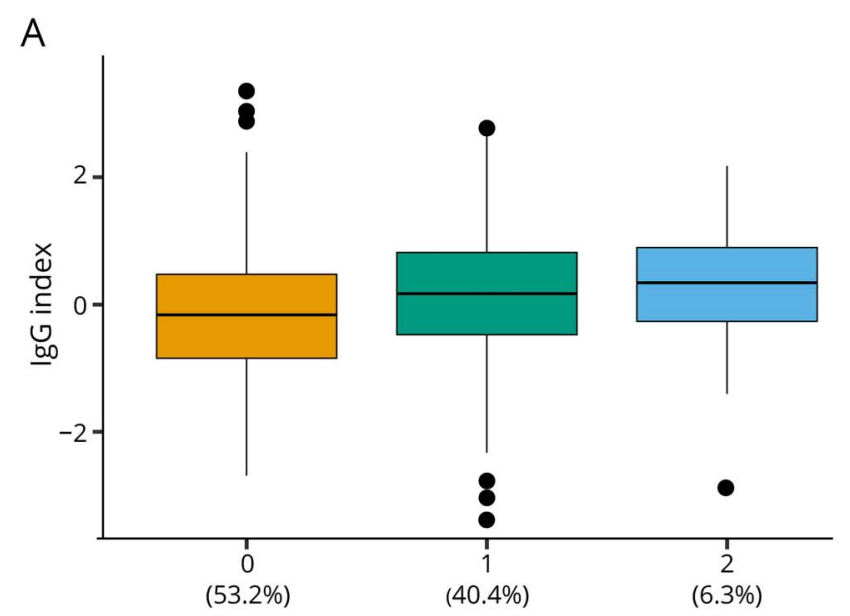

Number of copies HLA-DQB1*06:02

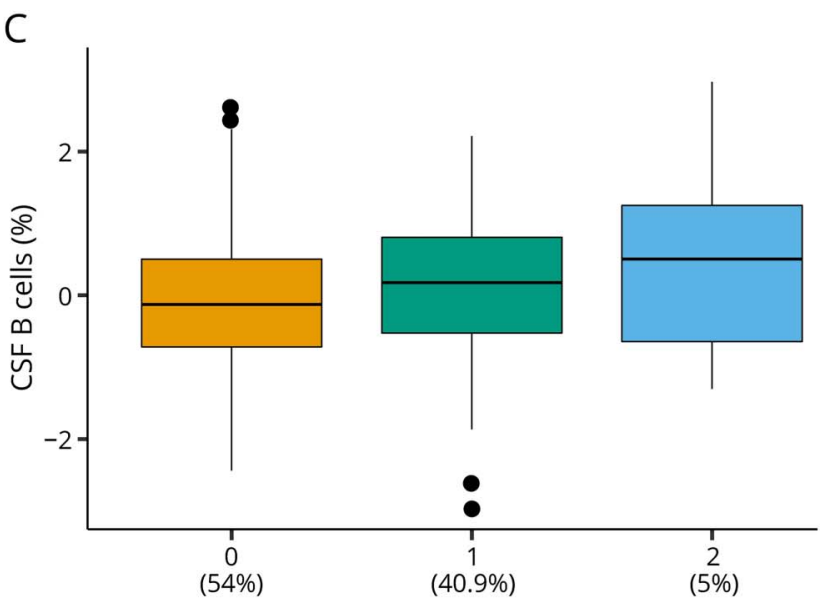

Number of copies HLA-DQB1 *06:02

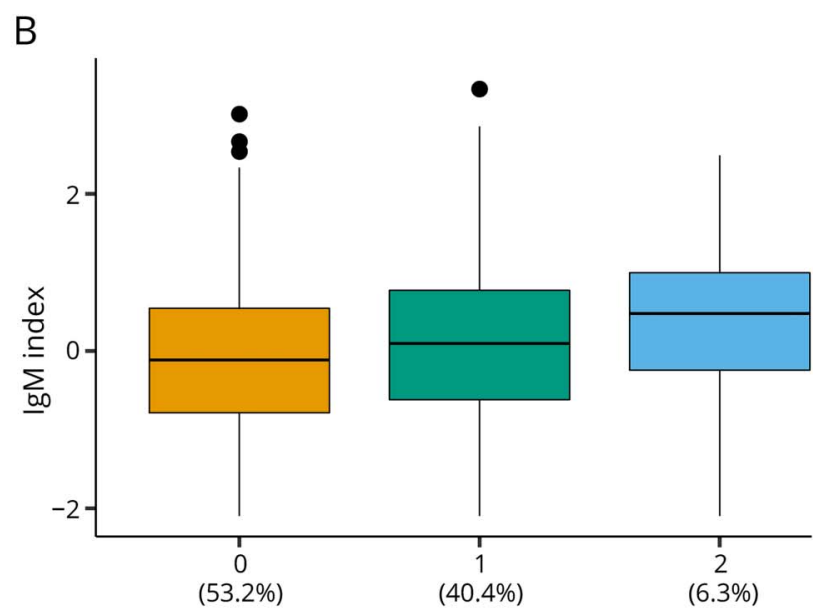

Number of copies HLA-DQB1 *06:02

D

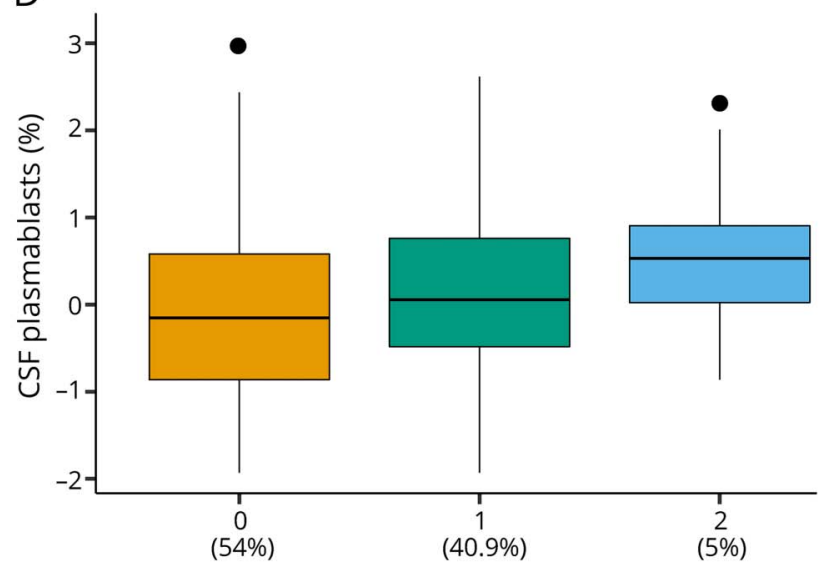

Number of copies HLA-DQB1 *06:02

Box plots showing the rank-transformed IgG indices (A), IgM indices (B), CSF B cell (C), and plasmablast (D) proportions (all transformed by inverse rank normalization) for noncarriers, heterozygotes, and homozygotes of HLA-DQB1*06:02. Bars represent the median, boxes the interquartile ranges, the vertical lines the data range without outliers, and dots the outliers.

and alleles from the HLA-B*07:02-DRB $1^{*} 15: 01-\mathrm{DQA} 1^{*} 01$ : 02-DQB1*06:02 haplotype on IgG indices or between rs 12897751 and HLA-C*02:02 on IgM levels. However, we observed evidence for epistatic interaction between rs 12897751 and HLA-B ${ }^{*} 44: 02$ on IgG indices (interaction term $\beta=-0.58[-0.94$ to -0.22$], p=6.12 \times 10^{-03}$, adjusted for 4 independent test, figure e-1C, links.lww.com/NXI/ A277) and between rs 12884389 and HLA alleles from the HLA-DQA1 ${ }^{*}$ 1:03-DQB1*06:03-DRB1*13:01 haplotype on IgA indices (interaction term for the haplotype and rs $12884389 \beta=-0.61[-0.97$ to -0.26$]$, adjusted $p=3.22 \times$ $10^{-03}$, figure e-1D, links.lww.com/NXI/A277).

\section{Discussion}

In this study, we report associations of genetic factors in 2 regions-the IGHC locus on chromosome 14 and the major histocompatibility complex (MHC) region on chromosome 6-with IgG, IgA, and IgM indices in patients with MS or CIS.
We confirmed and fine mapped a previously reported association between genetic variants at the IGHC locus and intrathecal IgG indices. ${ }^{5,6}$ The effect alleles of a highly correlated group of 10 SNPs were significantly associated with higher IgG indices. SNP rs12897751 - an intronic variant in the immunoglobulin heavy constant gamma 3 (IGHG3) gene-showed the most robust support for association. Another variant strongly associated with IgG indices, but not independently of rs12897751, was the missense variant rs1071803. Variant rs1071803 (in high LD with rs12897751, $r^{2}=0.95$ ) defines the IgG1 allotype G1m17 by altering the amino acid sequence of the $\mathrm{CH} 1$ domain of IgG1. The G1m17 allotype is part of the $\mathrm{Gm} 21^{*} ; 17,1 ; .$. and the $\mathrm{Gm} 21^{*} ; 17,1,2 ; .$. haplotypes, which are prevalent haplotypes in Caucasian and Mongoloid populations. ${ }^{23}$ The functional consequences of allotypes are poorly understood. Allotypes have been shown to correlate with IgG plasma concentrations ${ }^{24,25}$; they alter the IgG half-life ${ }^{26}$ and might influence the distribution of antibodies to specific tissues, affect class switching, or alter secondary messenger RNA 
Table 3 Association of HLA alleles with CSF B cells and plasmablasts

\begin{tabular}{|c|c|c|c|c|c|}
\hline \multirow[b]{2}{*}{ HLA allele } & \multirow[b]{2}{*}{ AF } & \multicolumn{2}{|c|}{$\begin{array}{l}\text { Regression on CSF B cell proportions } \\
\text { (no. of patients }=348 \text { ) }\end{array}$} & \multicolumn{2}{|c|}{$\begin{array}{l}\text { Regression on CSF plasmablast proportions } \\
\text { (no. of patients }=348 \text { ) }\end{array}$} \\
\hline & & $\beta(95 \% \mathrm{CI})$ & Adjusted $p$ & $\beta(95 \% \mathrm{CI})$ & Adjusted $p$ \\
\hline$B * 07: 02$ & 17.5 & $0.13(-0.06$ to 0.31$)$ & $8.90 \times 10^{-01}$ & $0.15(-0.03$ to 0.33$)$ & $5.35 \times 10^{-01}$ \\
\hline DQA1*01:02 & 32.3 & $0.19(0.03$ to 0.36$)$ & $1.17 \times 10^{-01}$ & 0.23 (0.07 to 0.39$)$ & $3.11 \times 10^{-02}$ \\
\hline DQB1*06:02 & 25.5 & $0.23(0.05$ to 0.40$)$ & $5.50 \times 10^{-02}$ & 0.23 (0.06 to 0.41$)$ & $3.74 \times 10^{-02}$ \\
\hline DRB1*15:01 & 26.7 & $0.23(0.06$ to 0.40$)$ & $4.45 \times 10^{-02}$ & 0.25 (0.08 to 0.42$)$ & $1.91 \times 10^{-02}$ \\
\hline DQA1*01:03 & 6.0 & $-0.12(-0.43$ to 0.20$)$ & $1.00 \times 10^{-00}$ & $-0.09(-0.40$ to 0.22$)$ & $1.00 \times 10^{-00}$ \\
\hline DQB1*06:03 & 5.5 & $-0.12(-0.43$ to 0.19$)$ & $1.00 \times 10^{-00}$ & $-0.04(-0.34$ to 0.27$)$ & $1.00 \times 10^{-00}$ \\
\hline DRB1*13:01 & 5.8 & $-0.13(-0.45$ to 0.19$)$ & $1.00 \times 10^{-00}$ & $-0.07(-0.39$ to 0.25$)$ & $1.00 \times 10^{-00}$ \\
\hline$B * 44: 02$ & 3.2 & $0.07(-0.35$ to 0.49$)$ & $1.00 \times 10^{-00}$ & $0.25(-0.16$ to 0.66$)$ & $1.00 \times 10^{-00}$ \\
\hline$C * 02: 02$ & 4.3 & $-0.57(-0.99$ to -0.14$)$ & $4.52 \times 10^{-02}$ & $-0.57(-0.91$ to -0.23$)$ & $5.35 \times 10^{-03}$ \\
\hline
\end{tabular}

Abbreviations: $\mathrm{AF}=$ allele frequency; $\mathrm{HLA}=$ human leukocyte antigen; $\mathrm{Ig}=$ immunoglobulin; IgA = immunoglobulin $\mathrm{A} ; \mathrm{IgG}=$ immunoglobulin $\mathrm{G} ; \mathrm{IgM}=$ immunoglobulin $M$; $L D=$ linkage disequilibrium.

Linear regression on CSF B cell and plasmablast proportions transformed by inverse rank normalization and 4-digit imputed HLA alleles. $p$ Values were adjusted by Bonferroni correction for multiple testing for $n=5$ tests (only HLA alleles associated with at least one of the lg indices were tested).

structures and affect the transcription rate. ${ }^{27,28}$ Although based on conditional analyses, rs 1071803 does not appear to be the causal variant for the association of the IGHC locus and the IgG index, it is however possible that other genetic variants causing Ig allotypy, not genotyped in the present study but in LD with the investigated variants, are causal for this relationship. Alternatively, as rs12897751 has been shown to be associated with higher protein expression levels of IGHG1, IGHG2, and IGHG3 (GTEx v8 ${ }^{29}$ ), an influence of this or another correlated variant at this locus on gene expression might affect IgG levels.

Most of the genetic variants on chromosome 14 associated with Ig indices were also associated with serum IgG levels. These associations were, however, much weaker than the associations with Ig indices. Variants at the IGHC locus might thus not only affect the amount of intrathecal Igs but also have some effect on serum IgG concentrations. Analysis of flow cytometry data from CSF cells showed an association of 2 SNPs on chromosome 14 with CSF B cells. As the effect alleles of these variants were, however, associated with lower CSF B cell proportions, it is unlikely that this explains their association with higher IgG indices.

Of interest, the minor alleles of all variants on chromosome 14 that were associated with higher IgG indices were, at the same time, associated with lower IgM and IgA indices. This is especially striking, as higher IgG indices were correlated with higher IgA and IgM indices. How the variants at the IGHC locus influence intrathecal IgM and IgA is, therefore, unclear; possible scenarios are an increased class switching to IgG-producing cells with resulting lower concentrations of IgA and IgM or feedback mechanisms resulting in reduced synthesis of IgM and IgA.
Eight HLA alleles were associated with Ig indices in this study. Alleles that are part of the extended HLA-DRB1*15: 01-DQA $1^{*} 01: 02-\mathrm{DQB1} 1^{*} 06: 02$ haplotype were significantly associated with higher IgG indices and nominally associated with higher $\operatorname{IgM}$ indices. The HLA-DRB1*15:01DQA1*01:02-DQB1 ${ }^{*} 06: 02$ haplotype showed the most robust support of association and HLA-DQB1*06:02 was the most significantly associated single allele. Causal mediation analysis showed that the effect of these HLA alleles on the $\operatorname{IgG}$ index is completely explained by their association with higher CSF B cell and plasmablast proportions. The same is true for the association of HLA- $C^{*} 02: 02$ with lower IgM indices and lower CSF B lymphocyte proportions. HLA-B ${ }^{*} 44: 02$ was independently associated with lower IgG indices, and we observed some evidence for epistasis between HLA-B* $44: 02$ and the top-associated IGHC variant rs12897751. The HLA-DQA1*01:03$\mathrm{DQB1}^{*} 06: 03-\mathrm{DRB} 1^{*} 13: 01$ haplotype and the individual HLA alleles that are part of this haplotype, on the other hand, were associated with higher IgA indices, but did not show any association with CSF B cells or plasmablasts. We did however observe evidence for epistatic interactions between the HLA-DQA1*01:03-DQB1 ${ }^{*} 06: 03-D R B 1{ }^{*} 13$ : 01 haplotype and IGHC variants. Different HLA alleles thus appear to have a differential effect on the intrathecal production of the Ig classes IgG, IgM, and IgA, probably due to different underlying mechanisms. Because of the design of this study, we cannot conclude whether the observed effects are specific for MS or possibly shared by other inflammatory neurologic diseases.

We describe 2 genetic regions-the IGHC locus on chromosome 14 and the MHC region on chromosome 6-that were associated with the amount of intrathecal $\operatorname{IgG}, \operatorname{IgM}$, 
and/or IgA in patients with MS or CIS. Our findings suggest differential mechanisms by which the 2 genetic regions influence intrathecal Ig synthesis or concentration (figure e-2, links.lww.com/NXI/A277). HLA alleles in LD with a known MS risk allele, HLA-DRB1*15:01, appeared to influence the proportion of intrathecal B cells and plasmablasts and thereby increase the intrathecal synthesis of immunoglobulins, especially of $\operatorname{IgG}$. The same was true for HLA-C*02:02 associated with lower CSF B lymphocyte proportions and IgM indices. The DQA1*01:03-DQB1 ${ }^{*}$ 06:03-DRB1*13:01 haplotype was associated with higher IgA indices, but not with higher CSF B lymphocyte proportions. We cannot conclude from the present study how these alleles influence CSF IgA levels.

Genetic variants at the IGHC locus on chromosome 14 were associated with higher IgG and lower IgA and IgM indices. These variants did not influence the composition of B lymphocytes in the CSF. We therefore believe that they might influence the amount of intrathecal Ig via other mechanisms, such as an altered CSF immunoglobulin homeostasis-probably as a result of changes of the protein structure caused by the variation in the amino acid sequence associated with the $\mathrm{Gm} 21^{*}$ haplotypes. Understanding the mechanisms by which the IGHC locus influences intrathecal Ig levels may have implications for the design of future therapeutic antibodies to ensure a better enrichment and persistence in the CNS compartment.

\section{Acknowledgment}

The authors thank all contributors of the study, especially the study nurses, for their motivated collaboration and recruitment efforts, all patients and relatives for their participation and support, and the data monitoring and administrative personnel of the German Competence Network of Multiple Sclerosis and the Klinikum rechts der Isar.

\section{Study funding}

The German National Multiple Sclerosis Cohort is supported by grants from the German Federal Ministry for Education and Research (grants 01GI0914 [Bochum], 01GI1601B [Marburg], and 01GI1601D [Munich]) and the German Research Foundation (DFG) in the framework of the Transregional Collaborative Research Center SFB CRC TR-128 (Drs Hemmer, Wiendl, Zipp, and Gold). Bernhard Hemmer received funding for the study by the European Union's Horizon 2020 Research and Innovation Program (grant MultipleMS, EU RIA 733161) and the Deutsche Forschungsgemeinschaft (DFG, German Research Foundation) under Germany's Excellence Strategy within the framework of the Munich Cluster for Systems Neurology (EXC 2145 SyNergy-ID 390857198). Bernhard Hemmer, Till Andlauer, Christiane Gasperi, Tania Kümpfel, Ulf Ziemann, and Antonios Bayas are associated with DIFUTURE (Data Integration for Future Medicine, BMBF 01ZZ1804 [A-I]). The biobank of the Department of Neurology as part of the Joint Biobank Munich in the framework of the German Biobank Node supported the study.

\section{Disclosure}

Dr. C. Gasperi received funding from the Deutsche Forschungsgemeinschaft (DFG, German Research Foundation). Dr. T. F. M. Andlauer and A. Keating report no disclosures relevant to the manuscript. Dr. B. Knier received funding from the Federal Ministry for Education and Research (grant from the German Competence Network of MS) and intramural funding from the Technical University of Munich. He received a research grant from Novartis outside the submitted work. Dr. A. Klein, Dr. V. Pernpeintner, and Dr. P. Lichtner report no disclosures relevant to the manuscript. Dr. R. Gold has received speaker's and board honoraria from Baxter, Bayer Schering, Biogen Idec, CLB Behring, Genzyme, Merck Serono, Novartis, Stendhal, Talecris, and Teva Pharmaceutical Industries and grant support (via his department) from Bayer Schering, Biogen Idec, Genzyme, Merck Serono, Novartis, and Teva Pharmaceutical Industries. Dr. F. Zipp has recently received research grants and/or consultation funds from DFG, BMBF, PMSA, MPG, Genzyme, Merck Serono, Roche Novartis, Sanofi Aventis, Celgene, ONO, and Octapharma. Dr. F. Then Bergh has received funding from the Deutsche Forschungsgemeinschaft; received through his institution, research support for investigator-initiated studies from Actelion and Novartis; served on scientific advisory boards for Novartis, Sanofi/Genzyme, and Roche; received support to attend a scientific meeting from Biogen; and received personal honoraria for speaking from Bayer Schering, Biogen, Roche, and Sanofi/Genzyme. Dr. M. Stangel has received honoraria for scientific lectures or consultancy from Bayer HealthCare, Biogen, Baxter/Baxalta, CSL Behring, Euroimmun, Grifols, Merck Serono, Novartis, Roche, Sanofi Aventis, and Teva Pharmaceutical Industries. His institution received research support from Bayer HealthCare, Biogen Idec, Genzyme, Merck Serono, Novartis, and Teva Pharmaceutical Industries. Dr. H. Tumani received speaker honoraria from Bayer, Biogen, Fresenius, Genzyme, Merck, Novartis, Roche, Siemens, and Teva; he or his institution has received research support from Fresenius, Genzyme, Merck, and Novartis, none related to this work. Dr. B. Wildemann has received research grants and/or honoraria from Merck Serono, Biogen, Teva, Novartis, Sanofi Genzyme, and Bayer HealthCare and research grants from the Dietmar Hopp Foundation, the Klaus Tschira Foundation, the Bundesministerium für Bildung und Forschung (BMBF), and the Deutsche Forschungsgemeinschaft (DFG). All conflicts are not relevant to the topic of the study. Dr. H. Wiendl receives honoraria for acting as a member of scientific advisory boards and as consultant for Biogen, Evgen, MedDay Pharmaceuticals, Merck Serono, Novartis, Roche Pharma AG, and Sanofi Genzyme, as well as speaker honoraria and travel support from Alexion, Biogen, Cognomed, F. Hoffmann-La Roche Ltd., Gemeinnützige Hertie-Stiftung, Merck Serono, Novartis, Roche Pharma AG, Sanofi Genzyme, Teva, and WebMD Global. Prof. Wiendl is acting as a paid consultant for AbbVie, Actelion, Biogen, IGES, Johnson 
\& Johnson, Novartis, Roche, Sanofi Genzyme, and the Swiss Multiple Sclerosis Society. His research is funded by the German Ministry for Education and Research (BMBF), Deutsche Forschungsgemeinschaft (DFG), Else Kröner Fresenius Foundation, Fresenius Foundation, Hertie Foundation, NRW Ministry of Education and Research, Interdisciplinary Center for Clinical Studies (IZKF) Muenster and RE Children's Foundation, Biogen $\mathrm{GmbH}$, GlaxoSmithKline $\mathrm{GmbH}$, Roche Pharma AG, and Sanofi Genzyme. Dr. A. Bayas has received personal compensation from Merck, Biogen, Bayer Vital, Novartis, Teva, Roche, Celgene, and Sanofi/Genzyme and grants for congress trips and participation from Biogen, Teva, Novartis, Sanofi/Genzyme, Celgene, and Merck. All conflicts are not relevant to the topic of the study. Dr. T. Kümpfel has received travel expenses and speaker honoraria from Bayer HealthCare, Teva Pharma, Merck, Novartis Pharma, Sanofi Aventis/Genzyme, CLB Behring, Roche Pharma, and Biogen as well as grant support from Bayer Schering AG, Novartis, and Chugai Pharma. All conflicts are not relevant to the topic of the study. Dr. U.K. Zettl has received research grants and/or speaker honorary from Almirall, Aventis, Bayer, Biogen, Merck Serono, Novartis, Roche, Teva, and Bundesministerium für Bildung und Forschung (BMBF). All conflicts are not relevant to the topic of the study. Dr. R.A. Linker received research support and/or personal compensation for activities with Bayer HealthCare, Biogen, Genzyme/Sanofi, Merck, Novartis Pharma, Roche, and Teva Pharma. Dr. U. Ziemann has received grants from European Research Council, German Research Foundation, German Ministry of Education and Research, Biogen Idec $\mathrm{GmbH}$, Servier, and Janssen Pharmaceuticals NV, all not related to this work, and consulting honoraria from Biogen Idec $\mathrm{GmbH}$, Bayer Vital GmbH, Bristol-Myers Squibb GmbH, Pfizer, CorTec $\mathrm{GmbH}$, and Medtronic $\mathrm{GmbH}$, all not related to this work. Dr. M. Knop received honoraria for serving on scientific advisory boards and as a speaker from Merck Serono, Novartis, Genzyme, Biogen, Pfizer/BMS, and Roche. Dr. C. Warnke received speaker honoraria (institutional only) and/or research funding from Biogen, Novartis, and Roche. Dr. M. A. Friese has received speaker honoraria from Biogen, Novartis, and EMD. All conflicts are not relevant to this study. Dr. F. Paul served on the steering committee for Novartis OCTIMS study and MedImmune; received speaker honoraria and travel funding from Bayer, Novartis, Biogen Idec, Teva, Sanofi Aventis/Genzyme, Merck Serono, Alexion, Chugai, and MedImmune; is an academic editor for PLoS One; is an associate editor for Neurology ${ }^{\circledR}$ : Neuroimmunology \& Neuroinflammation; has consulted for Sanofi Genzyme, Biogen Idec, and MedImmune; and received research support from Bayer, Novartis, Biogen Idec, Teva, Sanofi Aventis/Genzyme, Alexion, Merck Serono, German Research Council, Werth Stiftung of the City of Cologne, German Ministry of Education and Research (BMBF Competence Network Multiple Sclerosis), Guthy-Jackson Charitable Foundation, National Multiple Sclerosis Society, and Arthur Arnstein Stiftung Berlin. Dr. B. Tackenberg received personal speaker honoraria and consultancy fees as a speaker and advisor from Alexion, Bayer
HealthCare, Biogen, CSL Behring, Gilead, Grifols, Merck Serono, Novartis, Octapharma, Roche, Sanofi Genzyme, Teva, and UCB Pharma. His university received unrestricted research grants from Biogen Idec, Novartis, Teva, Bayer HealthCare, CSL Behring, Grifols, Octapharma, Sanofi Genzyme, and UCB Pharma. Dr. A. Berthele reports compensations for clinical trials received by his institution from Alexion Pharmaceuticals, Biogen, Novartis Pharmaceuticals, Roche, Sanofi Genzyme, and Teva Pharmaceuticals and personal fees and nonfinancial support from Bayer HealthCare, Biogen, Merck Serono, Mylan, Novartis Pharmaceuticals, Roche, and Sanofi Genzyme, all outside the work presented. Dr. B. Hemmer has served on scientific advisory boards for Novartis; he has served as DMSC member for AllergyCare, Polpharma, and TG Therapeutics; he or his institution has received speaker honoraria from Desitin; his institution received research grants from Regeneron for MS research; he holds part of 2 patents: one for the detection of antibodies against KIR4.1 in a subpopulation of patients with MS and one for genetic determinants of neutralizing antibodies to interferon. All conflicts are not relevant to the topic of the study. Go to Neurology. org/NN for full disclosures.

\section{Publication history}

Received by Neurology: Neuroimmunology \& Neuroinflammation February 28, 2020. Accepted in final form May 26, 2020.

\begin{tabular}{|c|c|c|}
\hline Name & Location & Contribution \\
\hline $\begin{array}{l}\text { Christiane } \\
\text { Gasperi, MD }\end{array}$ & $\begin{array}{l}\text { Technical University Munich, } \\
\text { Munich, Germany }\end{array}$ & $\begin{array}{l}\text { Designed and } \\
\text { conceptualized the } \\
\text { study; performed } \\
\text { statistical analyses; } \\
\text { and drafted the } \\
\text { manuscript }\end{array}$ \\
\hline $\begin{array}{l}\text { Till F.M. } \\
\text { Andlauer, PhD }\end{array}$ & $\begin{array}{l}\text { Technical University Munich, } \\
\text { Munich, Germany }\end{array}$ & $\begin{array}{l}\text { Acquired and } \\
\text { analyzed the data and } \\
\text { revised the } \\
\text { manuscript for } \\
\text { intellectual content }\end{array}$ \\
\hline $\begin{array}{l}\text { Ana Keating, } \\
\text { MSc }\end{array}$ & $\begin{array}{l}\text { Technical University Munich, } \\
\text { Munich, Germany }\end{array}$ & $\begin{array}{l}\text { Acquired and } \\
\text { analyzed the data and } \\
\text { revised the } \\
\text { manuscript for } \\
\text { intellectual content }\end{array}$ \\
\hline $\begin{array}{l}\text { Benjamin } \\
\text { Knier, MD }\end{array}$ & $\begin{array}{l}\text { Technical University Munich, } \\
\text { Munich, Germany }\end{array}$ & $\begin{array}{l}\text { Acquired and } \\
\text { analyzed the data and } \\
\text { revised the } \\
\text { manuscript for } \\
\text { intellectual content }\end{array}$ \\
\hline Ana Klein, MD & $\begin{array}{l}\text { Technical University Munich, } \\
\text { Munich, Germany }\end{array}$ & $\begin{array}{l}\text { Acquired and } \\
\text { analyzed the data and } \\
\text { revised the } \\
\text { manuscript for } \\
\text { intellectual content }\end{array}$ \\
\hline $\begin{array}{l}\text { Verena } \\
\text { Pernpeintner, } \\
\text { MD }\end{array}$ & $\begin{array}{l}\text { Technical University Munich, } \\
\text { Munich, Germany }\end{array}$ & $\begin{array}{l}\text { Acquired and } \\
\text { analyzed the data and } \\
\text { revised the } \\
\text { manuscript for } \\
\text { intellectual content }\end{array}$ \\
\hline
\end{tabular}


Appendix (continued)

\begin{tabular}{lll}
\hline Name & Location & Contribution \\
\hline $\begin{array}{l}\text { Peter } \\
\text { Lichtner, PhD }\end{array}$ & $\begin{array}{l}\text { Helmholtz Zentrum München, } \\
\text { Neuherberg, Germany }\end{array}$ & $\begin{array}{l}\text { Acquired and analyzed } \\
\text { the data and revised } \\
\text { the manuscript for } \\
\text { intellectual content }\end{array}$ \\
\hline Ralf Gold, MD & $\begin{array}{l}\text { Ruhr-University Bochum, } \\
\text { Bochum, Germany }\end{array}$ & $\begin{array}{l}\text { Acquired and } \\
\text { analyzed the data and } \\
\text { revised the } \\
\text { manuscript for } \\
\text { intellectual content }\end{array}$ \\
& & $\begin{array}{l}\text { Acquired and } \\
\text { analyzed the data and } \\
\text { revised the } \\
\text { manuscript for } \\
\text { Mrauke Zipp, } \\
\text { MD }\end{array}$ \\
& $\begin{array}{l}\text { Johannes Gutenberg } \\
\text { University Mainz, Mainz, } \\
\text { Germany }\end{array}$ & $\begin{array}{l}\text { intectual content } \\
\end{array}$ \\
\end{tabular}

$\begin{array}{ll}\text { Florian Then } & \text { University of Leipzig, Leipzig, } \\ \text { Bergh, MD } & \text { Germany }\end{array}$

Acquired and analyzed the data and revised the manuscript for intellectual content

\begin{tabular}{ll}
\hline Martin & Hannover Medical School, \\
Stangel, MD & Hannover, Germany
\end{tabular}

Acquired and analyzed the data and revised the manuscript for intellectual content

\begin{tabular}{ll}
\hline $\begin{array}{l}\text { Hayrettin } \\
\text { Tumani, MD }\end{array}$ & $\begin{array}{l}\text { Clinic of Neurology } \\
\text { Dietenbronn, Schwendi, } \\
\text { Germany }\end{array}$ \\
& \\
\hline $\begin{array}{l}\text { Brigitte } \\
\text { Wildemann, } \\
\text { MD }\end{array}$ & $\begin{array}{l}\text { University Hospital } \\
\text { Heidelberg, Heidelberg, } \\
\text { Germany }\end{array}$
\end{tabular}

Acquired and analyzed the data and revised the manuscript for intellectual content

Acquired and analyzed the data and revised the manuscript for intellectual content

\begin{tabular}{ll}
\hline Heinz Wiendl, & University of Münster, \\
MD & Münster, Germany
\end{tabular}

Acquired and analyzed the data and revised the manuscript for intellectual content

\begin{tabular}{ll}
\hline Antonios & University Hospital Augsburg, \\
Bayas, MD & Augsburg, Germany
\end{tabular}

Acquired and analyzed the data and revised the manuscript for intellectual content

\begin{tabular}{ll}
\hline Tania & Ludwig-Maximilians \\
Kümpfel, MD & University Munich, Munich, \\
& Germany
\end{tabular}

Acquired and analyzed the data and revised the manuscript for intellectual content

\begin{tabular}{ll}
\hline Uwe K. Zettl, & University of Rostock, \\
MD & Rostock, Germany
\end{tabular}

Acquired and analyzed the data and revised the manuscript for intellectual content

\begin{tabular}{lll}
\hline $\begin{array}{l}\text { Ralf A. Linker, } \\
\text { MD }\end{array}$ & $\begin{array}{l}\text { University of Regensburg, } \\
\text { Regensburg, Germany }\end{array}$ & $\begin{array}{l}\text { Acquired and } \\
\text { analyzed the data and } \\
\text { revised the } \\
\text { manuscript for } \\
\text { intellectual content }\end{array}$ \\
\hline $\begin{array}{ll}\text { UIf Ziemann, } \\
\text { MD }\end{array}$ & $\begin{array}{l}\text { Eberhard-Karls-Universität } \\
\text { Tübingen, Tübingen, Germany }\end{array}$ & $\begin{array}{l}\text { Acquired and } \\
\text { analyzed the data and } \\
\text { revised the } \\
\text { manuscript for } \\
\text { intellectual content }\end{array}$ \\
\hline
\end{tabular}

\section{Appendix (continued)}

\begin{tabular}{|c|c|c|}
\hline Name & Location & Contribution \\
\hline $\begin{array}{l}\text { Matthias } \\
\text { Knop, MD }\end{array}$ & $\begin{array}{l}\text { Max Planck Institute of } \\
\text { Psychiatry, Munich, Germany }\end{array}$ & $\begin{array}{l}\text { Acquired and } \\
\text { analyzed the data and } \\
\text { revised the } \\
\text { manuscript for } \\
\text { intellectual content }\end{array}$ \\
\hline $\begin{array}{l}\text { Clemens } \\
\text { Warnke, MD }\end{array}$ & $\begin{array}{l}\text { Medical Faculty, Heinrich } \\
\text { Heine University Düsseldorf, } \\
\text { Düsseldorf, Germany }\end{array}$ & $\begin{array}{l}\text { Acquired and } \\
\text { analyzed the data and } \\
\text { revised the } \\
\text { manuscript for } \\
\text { intellectual content }\end{array}$ \\
\hline $\begin{array}{l}\text { Manuel A. } \\
\text { Friese, MD }\end{array}$ & $\begin{array}{l}\text { University Medical Centre } \\
\text { Hamburg-Eppendorf, } \\
\text { Hamburg, Germany }\end{array}$ & $\begin{array}{l}\text { Acquired and } \\
\text { analyzed the data and } \\
\text { revised the } \\
\text { manuscript for } \\
\text { intellectual content }\end{array}$ \\
\hline $\begin{array}{l}\text { Friedemann } \\
\text { Paul, MD }\end{array}$ & $\begin{array}{l}\text { Charité-Universitätsmedizin } \\
\text { Berlin, Berlin, Germany }\end{array}$ & $\begin{array}{l}\text { Acquired and } \\
\text { analyzed the data and } \\
\text { revised the } \\
\text { manuscript for } \\
\text { intellectual content }\end{array}$ \\
\hline $\begin{array}{l}\text { Björn } \\
\text { Tackenberg, } \\
\text { MD }\end{array}$ & $\begin{array}{l}\text { Philipps-University Marburg, } \\
\text { Marburg, Germany }\end{array}$ & $\begin{array}{l}\text { Acquired and } \\
\text { analyzed the data and } \\
\text { revised the } \\
\text { manuscript for } \\
\text { intellectual content }\end{array}$ \\
\hline $\begin{array}{l}\text { Achim } \\
\text { Berthele, MD }\end{array}$ & $\begin{array}{l}\text { Technical University Munich, } \\
\text { Munich, Germany }\end{array}$ & $\begin{array}{l}\text { Acquired and } \\
\text { analyzed the data and } \\
\text { revised the } \\
\text { manuscript for } \\
\text { intellectual content }\end{array}$ \\
\hline $\begin{array}{l}\text { Bernhard } \\
\text { Hemmer, MD }\end{array}$ & $\begin{array}{l}\text { Technical University Munich, } \\
\text { Munich, Germany }\end{array}$ & $\begin{array}{l}\text { Designed and } \\
\text { conceptualized the } \\
\text { study; supervised the } \\
\text { research; and revised } \\
\text { the manuscript for } \\
\text { intellectual content }\end{array}$ \\
\hline
\end{tabular}

\section{References}

1. Reiber H, Ungefehr S, Jacobi C. The intrathecal, polyspecific and oligoclonal immune response in multiple sclerosis. Mult Scler 1998;4:111-117.

2. Bonnan M. Intrathecal IgG synthesis: a resistant and valuable target for future multiple sclerosis treatments. Mult Scler Int 2015;2015:296184.

3. Stauch C, Reiber H, Rauchenzauner M, et al. Intrathecal IgM synthesis in pediatric MS is not a negative prognostic marker of disease progression: quantitative versus qualitative IgM analysis. Mult Scler 2011;17:327-334.

4. Walsh MJ, Tourtellotte WW. Temporal invariance and clonal uniformity of brain and cerebrospinal IgG, IgA, and IgM in multiple sclerosis. J Exp Med 1986;163:41-53.

5. Buck D, Albrecht E, Aslam M, et al. Genetic variants in the immunoglobulin heavy chain locus are associated with the IgG index in multiple sclerosis. Ann Neurol 2013; 73:86-94.

6. Goris A, Pauwels I, Gustavsen MW, et al. Genetic variants are major determinants of CSF antibody levels in multiple sclerosis. Brain 2015;138:632-643.

7. Moutsianas L, Jostins L, Beecham AH, et al. Class II HLA interactions modulate genetic risk for multiple sclerosis. Nat Genet 2015;47:1107-1113.

8. Andlauer TF, Buck D, Antony G, et al. Novel multiple sclerosis susceptibility loci implicated in epigenetic regulation. Sci Adv 2016;2:e1501678.

9. von Bismarck O, Dankowski T, Ambrosius B, et al. Treatment choices and neuropsychological symptoms of a large cohort of early MS. Neurol Neuroimmunol Neuroinflamm 2018;5:e446. 10.1212/NXI.0000000000000446.

10. Poser CM, Paty DW, Scheinberg L, et al. New diagnostic criteria for multiple sclerosis: guidelines for research protocols. Ann Neurol 1983;13:227-231.

11. McDonald WI, Compston A, Edan G, et al. Recommended diagnostic criteria for multiple sclerosis: guidelines from the International Panel on the Diagnosis of Multiple Sclerosis. Ann Neurol 2001;50:121-127.

12. Polman $\mathrm{CH}$, Reingold SC, Edan G, et al. Diagnostic criteria for multiple sclerosis: 2005 revisions to the "McDonald Criteria". Ann Neurol 2005;58:840-846.

13. Polman CH, Reingold SC, Banwell B, et al. Diagnostic criteria for multiple sclerosis: 2010 revisions to the McDonald criteria. Ann Neurol 2011;69:292-302. 
14. Cepok S, Rosche B, Grummel V, et al. Short-lived plasma blasts are the main B cell effector subset during the course of multiple sclerosis. Brain 2005;128:1667-1676.

15. Teo YY, Inouye M, Small KS, et al. A genotype calling algorithm for the Illumina BeadArray platform. Bioinformatics 2007;23:2741-2746.

16. Purcell S, Neale B, Todd-Brown K, et al. PLINK: a tool set for whole-genome association and population-based linkage analyses. Am J Hum Genet 2007;81:559-575.

17. Chang CC, Chow CC, Tellier LC, Vattikuti S, Purcell SM, Lee JJ. Second-generation PLINK: rising to the challenge of larger and richer datasets. Gigascience 2015;4:7.

18. International HIV Controllers Study, Pereyra F, Jia X, McLaren PJ, et al. The major genetic determinants of HIV-1 control affect HLA class I peptide presentation. Science 2010;330:1551-1557.

19. Jia X, Han B, Onengut-Gumuscu S, et al. Imputing amino acid polymorphisms in human leukocyte antigens. PLoS One 2013;8:e64683.

20. Browning BL, Browning SR. A unified approach to genotype imputation and haplotype-phase inference for large data sets of trios and unrelated individuals. Am J Hum Genet 2009;84:210-223.

21. Tingley D, Yamamoto T, Hirose K, Keele L, Imai K. Mediation: R package for causal mediation analysis. J Stat Sotw 2014;59:1-38.

22. R Core Team. R: A Language and Environment for Statistical Computing. Vienna, Austria: R Core Team; 2018. Available at: https://www.R-project.org/.
23. Lefranc MP, Lefranc G. Human Gm, Km, and Am allotypes and their molecular characterization: a remarkable demonstration of polymorphism. In: Christiansen $\mathrm{F}$, Tait B, ed. Immunogenetics Methods in Molecular Biology (Methods and Protocols). Totowa: Humana Press, 2012.

24. Seppala IJ, Sarvas H, Makela O. Low concentrations of Gm allotypic subsets G3 mg and G1 mf in homozygotes and heterozygotes. J Immunol 1993;151:2529-2537.

25. Morell A, Skvaril F, Steinberg AG, Van Loghem E, Terry WD. Correlations between the concentrations of the four sub-classes of IgG and Gm Allotypes in normal human sera. J Immunol 1972;108:195-206.

26. Einarsdottir H, Ji Y, Visser R, et al. H435-containing immunoglobulin G3 allotypes are transported efficiently across the human placenta: implications for alloantibodymediated diseases of the newborn. Transfusion 2014;54:665-671.

27. Pan Q, Petit-Frere C, Hammarstrom L. An allotype-associated polymorphism in the gamma3 promoter determines the germ-line gamma3 transcriptional rate but does not influence switching and subsequent IgG3 production. Eur J Immunol 2000;30: 2388-2393.

28. Vidarsson G, Dekkers G, Rispens T. IgG subclasses and allotypes: from structure to effector functions. Front Immunol 2014;5:520.

29. Mele M, Ferreira PG, Reverter F, et al. Human genomics. The human transcriptome across tissues and individuals. Science 2015;348:660-665. 


\section{Neurology \\ Neuroimmunology \& Neuroinflammation}

Genetic determinants of the humoral immune response in MS

Christiane Gasperi, Till F.M. Andlauer, Ana Keating, et al.

Neurol Neuroimmunol Neuroinflamm 2020;7;

DOI 10.1212/NXI.0000000000000827

This information is current as of July 16, 2020

Neurol Neuroimmunol Neuroinflamm is an official journal of the American Academy of Neurology.

Published since April 2014, it is an open-access, online-only, continuous publication journal. Copyright

Copyright $\odot 2020$ The Author(s). Published by Wolters Kluwer Health, Inc. on behalf of the American

Academy of Neurology.. All rights reserved. Online ISSN: 2332-7812.

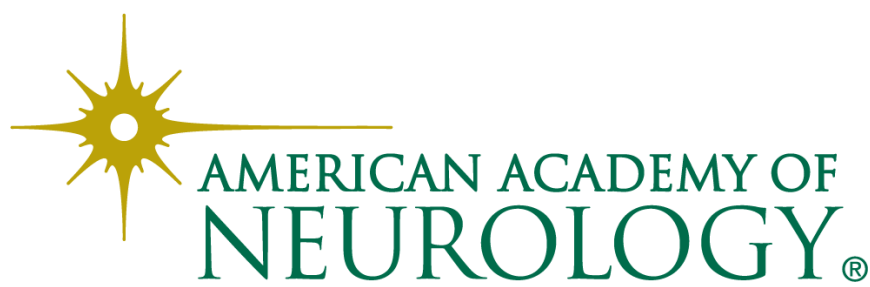




\section{Updated Information \& Services}

References

Citations

Subspecialty Collections

Permissions \& Licensing

Reprints including high resolution figures, can be found at: http://nn.neurology.org/content/7/5/e827.full.html

This article cites 27 articles, 7 of which you can access for free at: http://nn.neurology.org/content/7/5/e827.full.html\#\#ref-list-1

This article has been cited by 1 HighWire-hosted articles: http://nn.neurology.org/content/7/5/e827.full.html\#\#otherarticles

This article, along with others on similar topics, appears in the following collection(s):

Association studies in genetics

http://nn.neurology.org//cgi/collection/association_studies_in_genetics Autoimmune diseases

http://nn.neurology.org//cgi/collection/autoimmune_diseases

Cerebrospinal Fluid

http://nn.neurology.org//cgi/collection/cerebrospinal_fluid

Multiple sclerosis

http://nn.neurology.org//cgi/collection/multiple_sclerosis

Information about reproducing this article in parts (figures,tables) or in its entirety can be found online at:

http://nn.neurology.org/misc/about.xhtml\#permissions

Information about ordering reprints can be found online:

http://nn.neurology.org/misc/addir.xhtml\#reprintsus

Neurol Neuroimmunol Neuroinflamm is an official journal of the American Academy of Neurology.

Published since April 2014, it is an open-access, online-only, continuous publication journal. Copyright

Copyright $\odot 2020$ The Author(s). Published by Wolters Kluwer Health, Inc. on behalf of the American

Academy of Neurology.. All rights reserved. Online ISSN: 2332-7812.

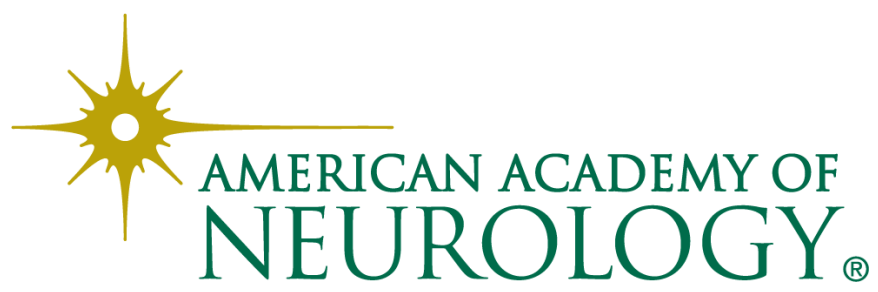

